Ulko Ye. M., Candidate of Economic Sciences, Postdoctoral Researcher Kharkiv National Agrarian University named after V.V. Dokuchayev; National Scientific Center «Institute for Soil Science and Agrochemistry Research named after O. N. Sokolovsky» Kharkiv, Ukraine

DOI: https://doi.org/10.30525/978-9934-26-080-3-7

\title{
SCIENTIFIC AND METHODOLOGICAL APPROACHES TO SUSTAINABLE MANAGEMENT LAND WITH USING ANTI-EROSION MODELING
}

Among the largest spread degradation processes at agriculture is soil (land) erosion in Ukraine. According to the data of the specialized scientific institution NSC «Institute for Soil Science and Agrochemistry Research named after O.N. Sokolovsky» under water erosion covers $17 \%$ arable land, and wind accounts for $11 \%$. At the same time, in aggregate, all varieties of soil erosion and deflation make up more than $30 \%$ total arable area. Separately, it should be noted that erosion processes aren't limited exclusively to their territorial limits (boundaries) distribution, since they have made a significant contribution, and sometimes «the most share», to other accompanying degradation phenomena. These include irrecoverable losses of humus, nutrients, problems with soil reclamation and etc. [1, p. 65]. 
By calculations A. V. Kucher, had shown that annual direct shortfall in production (loss of income (revenue) from sales) due to soil degradation in Ukraine is more than UAH 20 billion [2]. His methodological basis of the research is the fundamental provisions of modern economic theory, ecological economics and economics of land degradation. Separately, calculations show that the annual economic losses from erosion in Ukraine amount to UAH 5.7 bln or USD $0.224 \mathrm{bln}$, and whole volume of degradation accounts approximately USD 1.315 bln [2, p. 86]. These calculations basis on apply liner and quadratic econometric models (production functions) by Ukraine regions and Kharkiv region for concretely.

But such an assessment essentially depends on the peculiarities of the use of methodological approaches and the specific parameters included in the calculations.

At the same time, a significant number of publications indicate the amount of economic damage in excess of the above amount. So, O.L. Popova points out that according to the generally accepted expert estimation, the shortfall in grain production due to soil erosion is 9-12 mln tons annually [3]. And if we take the price of grain crops for 1 ton at UAH 3868, which is for agricultural enterprises in 2019, then, accordingly, the amount of direct losses will vary from 34.8 to 46.4 bln UAH, or from 1.35 to 1.78 bln US dollars (in 2019 UAH 25.85 / USD). It should be especially noted that in terms of annual losses of productive moisture, direct losses from grain shortfalls amount to $16 \mathrm{mln}$ tons.

Hence, we already get quite significant differences in the usual comparison of simpler approaches to assessing economic damage. However, it is the distribution of losses by grain that ranges from 0.224 to 1.780 bln USD, or almost 8 times. According to O.L. Popova, the loss of the monetary value of Ukrainian lands due to erosion is at the level of 15-20 bln USD [3].

Moreover, the problem of the formation of rental income (economic rent) from land is closely related to the management mechanisms on anti-erosion basis. In whole, the formation of sustainable economic development of the agricultural sector is 
impossible without compliance with the systemic requirements to flexibility, efficiency, accessibility (inclusion), the presence of competition in land issues, which are ultimately designed for create a fair and responsible use the rent in society. Coordination formation of rent in accordance with ensuring the preservation of soil fertility, their protection should be the prerogative both as the state and in society too. But with today's existing economic model, this can't take place, if don't be to make radical changes here [4]. Confirmation of the unbalance in the distribution of rent can be the presence of a discrepancy between the amount of rent payments and the calculated index of constant competitiveness of agricultural enterprises (SCI) [5, p. 82-83].

However, no less significant differences are noted in the ecological loss due to soil erosion. The differences in estimations are generated by a number of different reasons, but the primary basis is formed by the existence of estimations of physical consequences. Another factor is haven't a unified methodological approach and criterion for assessing losses for both the economic and ecological components. The problems of free interpretation and multiplicity of indicators of the damage caused are exacerbated by a flaw in a single algorithm to prevent the duality of scaling the cost of losses due to erosion. In this case, it's necessary to determination clearly possible manifestation of the duality consequences across erosion and to strengthen their causeand-effect relationships [6].

A significant potential in modeling the effectiveness of anti-erosion measures remains with the selection of crops and optimization of the structure of crops, since they have different degrees of resistance to manifestations of erosion. Along with this, it is important to balance the structure of agricultural crops in terms of the impact on minimizing the manifestations of humus deficiency and the degree of erosion hazard of lands. Also, the scale of modeling has going beyond the limits of small land tracts and prevail over large territories, including within the districts or regions of Ukraine.

The organization and implementation of modeling the effectiveness of anti-erosion measures to achieve (ensure) sustainable 
development of land (soil) resources involves the development and compliance with various procedures. As a result of the initial (preliminary) analysis, the following were identified:

1) in the management of soil fertility and the efficiency of the use of land resources in modern conditions, the development of models and their use remains insignificant, and these processes occur mainly without scientifically based decisions and strategic guidelines, which should be provided with basic plans for solving economic and mathematical problems;

2) insufficient attention is paid to organizational and economic conditions, and often economic indicators are not taken into account;

3 ) when modeling, it is necessary to take into account not only the targeted recommendations of scientists and the vision of the model developer, but also include a set of needs on the part of the agricultural business, land share holders and relevant government agencies;

4) the developed model should be environmentally and economically oriented, take into account the balance of environmental parameters, harmonize them with economic feasibility, be attractive for potential investors and for existing agricultural producers;

5) the selection of the target function should be justified based on the existing scientific recommendations and tasks set by the researcher, the available information base;

6) the inclusion of technological norms of the model is aimed at expanding the possibilities of actual and potential data for determining the optimal parameters to prevent erosion processes;

7) restrictions impose the nature of the optimality of the values (unknown) and the stability of the results obtained and their estimated value depend on their correct inclusion in the calculation;

8) one of the important regulatory ways to reduce the consequences of erosion is to further improve the development of models based on optimizing the structure of crops for agricultural crops and subject to a number of restrictions related to minimizing humus deficiency and soil erosion hazard. Such measures are capable of providing an 
increase in profitability (profitability) in a wide range from 10 to $50 \%$ or more.

\section{References:}

1. Ulko Ye.M. (2019) Orhanizatsiino-ekonomichni umovy minimizatsii rozvytku eroziinykh protsesiv u silskohospodarskomu zemlekorystuvanni Ukrainy [Organizational and Economic Conditions for Minimizing the Development of Erosion Processes in Agricultural Land Use in Ukraine]. Proceedings of the Intern. scient.pract. conf. Sustainable innovative and creative development of socio-economic systems, (Ukraine, Berezhany, October 21, 2019), Berezhany: SE NULES of Ukraine «BATI», 2019. Pp. 65-68.

2. Kucher A.V. (2019) Sustainable soil management in the formation of competi-tiveness of agricultural enterprises: monograph. Plovdiv: Academic Publishing House «Talent», $444 \mathrm{p}$.

3. Popova O.L. (2013) Otsinka suspilnykh zbytkiv i rozmiru vidshkoduvannia za pohirshennia yakosti silskohospodarskykh zemel [Estimation of social losses and the size of a compensation for a deterioration of the quality of farming lands]. Ekonomika Ukrainy [Economy of Ukraine]. Vol. 3(616). Pp. 47-56. (in Ukraine)

4. Ulko Ye.M. (2019) Rentni vidnosyny za protyeroziinoi systemy vykorystannia zemelnykh resursiv [Rent Relations under the Anti-Erosion System of Land Use]. Proceedings of the Intern. scient.-pract. conf. dedicated 90-th anniversary of the economy education at KhNAU V.V. Dokuchayeva, (Ukraine, Kharkiv, October 3-4, 2019), Kharkiv : KhNAU. Part 1. Pp. 255-259.

5. Kucher A.V. (2019) Zonalni osoblyvosti formuvannia y rezervy pidvyshchennia staloi konkurentospromozhnosti ahrarnykh pidpryiemstv [Zonal Features of Formation and Reserves of Increasing the Sustainable Competitiveness of Agricultural Enterprises]. Agricultural and Resource Economics: International Scientific E-Journal. Vol. 5. No. 3. Pp. 77-105. (in Ukraine)

6. Ulko Ye.M. (2021) Problemy ekoloho-ekonomichnoi otsinky masshtabu naslidkiv vid erozii zemelnykh (hruntovykh) resursiv Ukrainy [Problems of ecological and economic estimation to scale consequences from erosion of land (soil) resources in Ukraine]. Proceedings of the II Intern. scient.-pract. conf. Sustainable development of the agricultural sector: engineering and economic support (Ukraine, Berezhany, February 22, 2021), Kharkiv : Ltd «PromArt». Pp. 17-18. 